\title{
Pengaruh Profitabilitas, Leverage dan Ukuran Perusahaan pada Tax Avoidance
}

\author{
Ni Ketut Rai Riskatari ${ }^{1}$ \\ Fakultas Ekonomi dan Bisnis \\ Universitas Udayana, Indonesia \\ Email: riskatarinew16@gmail.com
}

\author{
I Ketut Jati ${ }^{2}$ \\ Fakultas Ekonomi dan Bisnis \\ Universitas Udayana, Indonesia
}

\begin{abstract}
ABSTRAK
Tax avoidance merupakan upaya yang dilakukan oleh wajib pajak untuk mengurangi utang pajak secara legal dengan cara memanfaatkanloophole dari peraturan perpajakan. Tax avoidance merupakan persoalan yang unik dan rumit, di satu sisi tax avoidance diperbolehkan tetapi disisi lain tax avoidance tidak diinginkan oleh pemerintah. Penelitian ini dilakukan pada perusahaan property dan real estate yang terdaftar di Bursa Efek Indonesia (BEI) periode 2014-2018. Pemilihan sampel pada penelitian ini menggunakan teknik purposive sampling dengan kriteria yang telah ditentukan dan diperoleh sampel sebanyak 22 perusahaan. Teknik analisis data yang digunakan yaitu a nalis is regresi linier berganda. Metode pengujian hipotesis menggunakan tingkat signifikansisebesar 5 persen. Berdasarkan hasil penelitian menunjukkan bahwa variabel profitabilitas berpengaruh negatif pada tax avoidance, variabel leverage berpengaruh positif pada tax avoidance dan ukuran perus ahaa $\mathrm{n}$ berpengaruh positif pada tax avoidance.
\end{abstract}

Kata Kunci: Tax Avoidance; Profitabilitas; Leverage dan Ukuran Perusahaan.

\section{The Effect of Profitability, Leverage and Firm Size on Tax Avoidance}

ABSTRACT

Tax avoidance is an effort made by taxpayers to reduce tax debtlegally by utilizing loophole from tax regulations. Tax avoidance is a unique and complicated problem, on the one hand tax avoidance is allowed but on the other hand tax avoidance is not desired by the government. This research was conducted on property and real estate companies listed on the Indonesia Stock Exchange (BEI) for the 2014-2018 period. The sample selection in this study uses a purposive sampling technique with predetermined criteria and a sample of 22 companies is obtained. The data analysis technique used is multiple linear regression analysis. The hypothesis testing method uses a significance level of 5 percent. B ased on the results of the study indicate that the profitability variable has a negative effecton tax avoidance, leverage variable has a positive effect on tax avoidance and company size has a positive effect on tax avoidance.

Keywords: $\quad$ Tax Avoidance; Profitability; Leverage; Firm Size.

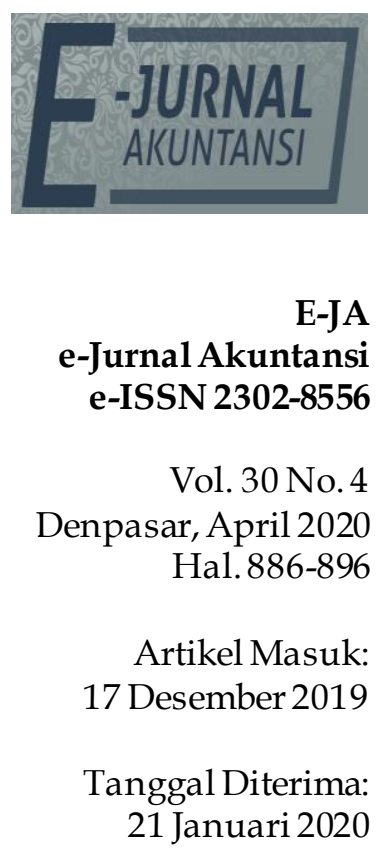

E-JA

-Jurnal Akuntansi

Vol. 30 No. 4

, April 2020

Artikel Masuk:

anggal Diterima:

21 Januari 2020 


\section{PENDAHULUAN}

Faktor utama yang menjadikan para wajib pajak melakukan tindakan penggelapan pajak (tax evasion) adalah karena untuk melakukan penghindaran pajak (tax avoidance) diperlukan wawasan dan pengetahuan yang luas serta berkompeten di bidangnya dan mengetahui semua seluk-beluk peraturan perundang-undangan tentang perpajakan sehingga dapat menemukan celah yang dapat ditembus untuk mengurangi beban pajak yang dibayarkan tanpa melanggar peraturan yang ada. Biasanya hal seperti ini dilakukan oleh para penawar jasa konsultan pajak, sehingga wajib pajak yang kurang memahami celah-celah dalam Undang-Undang perpajakan lebih memilih untuk melakukan penggelapan pajak (tax evasion) karena lebih gampang dilakukan walaupun itu merupakan tindakan yang melanggar Undang-Undang. Penggelapan pajak ini dilakukan dengan menggunakan cara yang tidak legal. Para wajib pajak mengabaikan ketentuan formal perpajakan yang menjadi kewajibannya, memalsukan dokumen, atau mengisi data dengan tidak lengkap dan tidak benar.

Perilaku penggelapan pajak ( tax evasion) yang dilakukan oleh Wajib Pajak (WP) memiliki konsekuensi yang sangat beresiko secara materil dan non materil. Secara materil bahwa WP akan menganggap perbuatan penggelapan pajak itu akan menguntungkannya secara jangka panjang, akan tetapi konsekuensi yang terjadi jika terungkapnya tindakan penggelapan pajak tersebut, maka WP akan membayar dengan kerugian berlipat ganda disertai dengan denda dan kurungan pidana dalam jangka waktu tertentu, ditambah pula jika WP tidak mempunyai cukup dana untuk menutup denda yang diputuskan, sejumlah asset akan disita dan bisa berdampak pada kebangkrutan bahkan resiko kejiwaan (Sa'diyah, 2016).

Tabel 1. Target dan Realisasi Penerimaan Pajak Indonesia Tahun 2014-2018 (dalam triliun rupiah)

\begin{tabular}{|c|c|c|c|c|c|}
\hline Tahun & 2014 & 2015 & 2016 & 2017 & 2018 \\
\hline Target & & & & & \\
\hline Pajak & $1.072,37$ & $1.294,26$ & $1.355,20$ & $1.283,57$ & $1.424,00$ \\
\hline Realisasi & & & & & \\
\hline Pajak & 981,83 & $1.060,83$ & $1.105,81$ & $1.151,03$ & $1.315,51$ \\
\hline Persentase & & & & & \\
\hline $\begin{array}{l}\text { Penerimaa } \\
\text { n Pajak }\end{array}$ & $91,56 \%$ & $81,96 \%$ & $81,60 \%$ & $89,67 \%$ & $92,24 \%$ \\
\hline
\end{tabular}

Sumber: Menu Kerja Penerimaan Portal Direktorat Jenderal Pajak, 2019.

Berdasarkan data pada Tabel 1. dapat disimpulkan bahwa persentase realisasi penerimaan negara dari sejak tahun 2014-2018 mengalami penurunan dan peningkatan. Penurunan dari tahun 2014 ke tahun 2015 sebesar 9,6\%. Penurunan dari tahun 2015 ke tahun 2016 sebesar 0,36\%. Peningkatan dari tahun 2016 ke tahun 2017 sebesar 8,07\% dan pada tahun 2017 ke tahun 2018 sebesar $2,57 \%$, walaupun mengalami peningkatan penerimaan pajak namun realisasi penerimaan pajak belum mampu mencapai target yang ditentukan. Hal ini menandakan bahwa belum stabil dan optimalnya penerimaan pajak sebagai sumber pendapatan negara yang akan digunakan untuk membiayai keperluan negara. Teori perilaku terencana membantu menjelaskan kecendrungan penghindaran pajak perusahaan yang direncanakan, (Hidayat \& Adhi, 2010) 
menyatakan bahwa perilaku individu tidak patuh terhadap ketentuan perpajakan dipengaruhi oleh niat (intention) untuk berperilaku tidak patuh. Teori ini juga berpendapat bahwa individu akan melakukan apa saja yang dapat menguntungkan dirinya sendiri atau dengan kata lain teroi ini menjelaskan perilaku seseorang berdasarkan niat atau rencana (Bahari, 2016). Theory of Planned Behavior (TPB) relevan untuk menjelaskan perilaku wajib pajak dalam memenuhi kewajiban perpajakannya. Sebelum individu melakukan sesuatu, individu tersebut akan memiliki keyakinan mengenai hasil yang akan diperoleh dari perilakunya tersebut. Kemudian bersangkutan akan memutuskan bahwa akan melakukannya atau tidak melakukannya. Wajib pajak yang sadar pajak, akan memiliki keyakinan pentingnya membayar pajak (behavioral beliefs). Wajib Pajak yang tidak sadar akan pentingnya membayar pajak, rasionalitasnya akan memengaruhi penentuan perilaku tindakan penghindaran pajak.

Trade-off Theory menyatakan tentang hubungan antara struktur modal dengan nilai perusahaan. Trade-off Theory berasumsi bahwa perusahaan akan menggunakan hutang sampai tingkat tertentu untuk memaksimalkan nilai perusahaan dengan memanfaatkan pajak akibat penggunaan hutang. Model trade-off theory juga berasumsi bahwa struktur modal perusahaan merupakan hasil trade-off dari keuntungan pajak dengan menggunakan hutang dengan biaya bunga yang akan timbul sebagai akibat penggunaan hutang tersebut. Esensi Trade-off Theory bahwa penetapan struktur modal yang dikatakan optimal dapat terwujud saat terjadinya kesetaraan antara pengeluaran yang terjadi dengan manfaat yang diterima atas keputusan penggunaan utang oleh perusahaan.

Sesuai dengan Theory of Planned Behaviour, dapat digunakan untuk menjelaskan perilaku wajib pajak dalam memenuhi kewajiban perpajakannya. Terkait dengan behavioural beliefs, yaitu sebelum individu melakukan sesuatu, individu tersebut akan memiliki keyakinan mengenai hasil yang akan diperoleh dari perilakunya tersebut. Kemudian yang bersangkutan akan memutuskan bahwa akan melakukannya atau tidak melakukannya (Mustikasari, 2007). Control beliefs memengaruhi perusahaan untuk melakukan tindakan tax avoidance atau tidak. Control beliefs merupakan keyakinan tentang keberadaan hal-hal yang mendukung atau menghambat perilakunya dan persepsinya tentang seberapa kuat hal-hal tersebut memengaruhi perilakunya. Ketika perusahaan memiliki profitabilitas yang tinggi, maka perusahaan akan memiliki niat atau keinginan untuk merencanakan perilaku yang tidak patuh membayar pajak karena tingginya beban pajak yang harus ditanggung perusahaan dari peningkatan profit perusahaan. Keyakinan yang dimiliki perusahaan ini mendorong control beliefs. Perusahaan yang memiliki laba bersih yang tinggi memiliki kesempatan untuk memposisikan diri dalam tax planning yang mengurangi jumlah beban kewajiban pajaknya (Ariawan \& Setiawan, 2017). Penelitian terkait pernah dilakukan oleh Darmawan \& Sukartha (2014), Waluyo et al., (2015), Dewinta \& Setiawan (2016), Saputra et al., (2015) yang menyatakan bahwa profitabilitas berpengaruh positif pada tax avoidance.

Sesuai dengan Theory of Planned Behaviour, ketika manajer yakin akan adanya hasil yang menguntungkan dari memanfaatkan hutang yang tinggi untuk mengurangi beban pajak, maka perusahaan akan berencana untuk 
melakukan perilaku curang dengan melakukan tax avoidance. Control beliefs juga mempengaruhi perusahaan untuk melakukan tindakan penghindaran pajak. Control beliefs merupakan keyakinan tentang keberadaan hal-hal yang mendukung atau menghambat perilakunya dan persepsinya tentang seberapa kuat hal-hal tersebut mempengaruhi perilakunya. Ketika perusahaan mengetahui bahwa dalam UU Nomor 36 Tahun 2008 ketentuan Pasal 6 ay at (1) huruf a, dijelaskan bahwa penghasilan kena pajak bagi wajib pajak dalam negeri dan badan usaha tetap, ditentukan berdasarkan penghasilan bruto dikurangi biaya yang berkaitan dengan kegiatan usaha termasuk salah satunya biaya bunga. Dengan dijelaskannya dalam UU tersebut maka perusahaan memiliki keyakinan yang mendukung perilakunya untuk melakukan tindakan penghindaran pajak, dengan memanfaatkan utang sampai tingkat tertentu untuk menghemat pembayaran pajak perusahaan karena adanya beban bunga yang harus dibayarkan. Penelitian terkait pernah dilakukan oleh Rachmithasari (2015), Praditasari \& Setiawan (2017), Handayani (2017), Ayuningtyas \& Sujana (2018) serta Arianandini \& Ramantha (2018) yang menyatakan leverage berpengaruh positif pada tax avoidance.

Sesuai dengan Theory of Planned Behaviour menjelaskan bahwa adanya perilaku tertentu, disebabkam oleh niat atau keinginan seorang individu untuk melakukan hal tersebut. Dalam Theory of Planned Behaviour, ukuran perusahaan berkaitan dengan behavioural beliefs merupakan keyakinan individu akan hasil dari suatu perilaku dan evaluasi atas hasil tersebut. Keyakinan dan evaluasi ini akan membentuk variabel sikap yang akan mempengaruhi perilaku individu. Perusahaan yang umumnya memiliki ukuran yang besar diharapkan dapat menghasilkan laba yang besar melalui pengelolaan aktiva yang dimiliki serta transaksi yang kompleks dalam perusahaan tersebut, apabila laba perusahaan meningkat maka perusahaan akan berusaha untuk meminimalkan beban pajaknya karena laba yang besar akan mempengaruhi beban pajak per usahaan. Hal tersebut membuat perusahaan berniat untuk melakukan tindakan tax avoidance yang dapat menghemat besarnya jumlah pajak perusahan. Penelitian terkait pernah dilakukan oleh Dewinta \& Setiawan (2016),), Putri \& Putra (2017), Diantari \& Ulupui (2016), Dharma \& Ardiana (2016), Swingly \& Sukartha (2015), serta Dewi \& Noviari (2017) yang menyatakan ukuran perusahaan berpengar uh positif pada tax avoidance.

\section{METODE PENELITIAN}

Lokasi penelitian ini adalah di Bursa Efek Indonesia (BEI) yang menyediakan informasi laporan keuangan perusahaan dengan mengakses situs resmi BEI yaitu www.idx.co.id. Alasan memilih lokasi penelitian tersebut karena perusahaanperusahaan yang terdaftar di BEI melaporkan laporan keuangan secara lengkap. Objek yang digunakan dalam peneitian ini adalah perusahaan property dan real estate yang terdaftar di BEI periode 2014-2018 (5 tahun).

Populasi pada penelitian ini adalah seluruh perusahaan property dan real estate yang terdaftar di Bursa Efek Indonesia (BEI) pada periode 2014-2018 yang berjumlah sebanyak 48 perusahaan. Sampel pada penelitian ini adalah perusahaan property dan real estate yang terdaftar di BEI periode 2014-2018. Jumlah sampel dalam penelitian ini adalah 22 sampel perusahaan yang sesuai 
dengan kriteria sampel. Namun kriteria yang tidak sesuai dengan yang ditetapkan peneliti dikeluarkan dari sampel. Model regresi linier berganda dalam penelitian ini menggunakan program Statistical Package for Social Science (SPSS). Adapun model regresi linier berganda dalam penelitian ini ditunjukkan oleh persamaan berikut.

$Y=\alpha+\beta_{1} X_{1}+\beta_{2} X_{2}+\beta_{3} X_{3}+\varepsilon$

Keterangan.

Y : Tax avoidance

a $\quad$ : Nilai Intersep Konstanta

$\beta_{1}-\beta_{3}$ : Koefisien regresi variabel $X_{1}, X_{2}, X_{3}$

$\mathrm{X}_{1} \quad$ : Profitabilitas

$\mathrm{X}_{2} \quad$ : Leverage

$\mathrm{X}_{3}$ : Ukuran perusahaan

$\varepsilon \quad$ : Error

Dari hasil analisis regresi akan diamati koefesien adjusted $\mathrm{R}$ square, uji kelayakan model (Uji F) dan uji statistik $\mathrm{t}$ (Uji t).

\section{HASIL DAN PEMBAHASAN}

Uji normalitas dalam penelitian ini bertujuan untuk menguji apakah residual dari model regresi yang dibuat berdistribusi normal atau tidak. Dalam penelitian ini uji normalitas dilakukan dengan menguji normalitas residual dengan menggunakan Uji Kolmogrov Smirnov. Data penelitian yang digunakan dikatakan berdistribusi normal apabila nilai Asymp. Sig. (2-tailed) lebih besar dari a = 0,05. Hasil uji normalitas dalam penelitian ini dapat dilihat pada Tabel 2.

Tabel 2. Hasil Uji Normalitas

\begin{tabular}{lll}
\hline & & Unstandardized Residual \\
\hline Normal Parametrsa.b & Mean & 110 \\
& Std. Deviation & 0,0000000 \\
MostExtreme & Absolute & 0,12338697 \\
Differences & Positive & 0,067 \\
& Negative & 0,067 \\
Kolmogorov-Smirnov Z & & $-0,049$ \\
Asymp.Sig,(2-tiled) & & 0,707 \\
\hline
\end{tabular}

Sumber: Data Penelitian, 2019

Berdasarkan hasil uji normalitas pada Tabel 2. menunjukkan bahwa Asymp. Sig. (2-tailed) sebesar 0,699 lebih besar dari level of significant (tingkat signifiknasi) 0,05 maka dapat disimpulkan bahwa model persamaan regresi berdistribusi normal.

Uji multikolinearitas dalam penelitian ini bertujuan untuk menguji apakah dalam satu model regresi ditemukan adanya korelasi antar variabel bebas (independen). Model regresi yang baik seharusnya tidak terjadi koreasi di antara variabel independen. Untuk mendeteksi ada atau tidaknya korelasi antar variabel bebas dapat dilihat dari nilai tolerance dan nilai Variance Inflation Factor (VIF). Jika nilai tolerance lebih dari 10 persen atau VIF kurang dari 10, maka dapat dikatakan bebas dari multikolinearitas. Hasi uji multikoleniaritas dapat dilihat pada Tabel 3 . 


\section{Tabel 3. Hasil Uji Multikolinearitas}

\begin{tabular}{lll}
\hline \multirow{2}{*}{ Model } & Collinearity Statistics \\
\cline { 2 - 3 } & Tolerance & VIF \\
\hline (Constant) & 0,917 & 1,091 \\
Profitabilitas & 0,966 & 1,036 \\
Leverage & 0,917 & 1,091 \\
Ukuran P & & \\
\hline
\end{tabular}

Sumber: Data Penelitian, 2019

Berdasarkan hasil uji multikoleniaritas pada Tabel 3. menunjukkan bahwa variabel bebas dalam penelitian ini yaitu profitabilitas, leverage dan ukuran perusahaan memiliki nilai tolerance $>0,10$ atau nilai VIF $<10$. Maka, dapat disimpulkan bahwa variabel bebas dalam penelitian ini terbebas dari multikoleniaritas atau tidak ada korelasi antar variabel bebas.

Uji heteroskedastisitas dalam penelitian ini bertujuan untuk menguji apakah dalam model regresi terjadi ketidaksamaan variance dari residual satu pengamatan ke pengamatan lain. Pengujian ini dilakukan dengan Uji Glejser, yaitu dengan cara meregresi nilai absolute residual dari model yang diestemasi terhadap variabel independen. Model regresi yang baik adalah yang tidak mengandung gejala heteroskedastisitas yaitu keadaan ketika varians dari residual satu pengamtan ke pengamatan lain adalah tetap yang disebut homokedastisitas. Jika variabel bebas yang diteliti tidak mempunyai pengar uh signifikan atau nilai signifikansinya lebih dari 0,05 terhadap nilai absolute residual, berarti model regresi tidak mengandung gejala heteroskedastisitas.

Tabel 4. Hasil Uji Heteroskedastisitas

\begin{tabular}{lll}
\hline \multicolumn{2}{l}{ Model } & Sig \\
\hline $1 \quad$ (Constant) & 0,978 \\
& Profitabilitas & 0,913 \\
& Leverage & 0,139 \\
& Ukuran P & 0,642 \\
\hline
\end{tabular}

Sumber: Data Penelitian, 2019

Berdasarkan hasil uji heteroskedastisitas pada Tabel 4. menunjukkan bahwa nilai Sig. dari masing-masing variabel bebas yaitu profitabilitas, leverage dan ukuran perusahaan terhadap variabel absolut residual berada diatas 0,05 maka, dapat disimpulkan bahwa data yang digunkan pada penelitian ini bebas gejala heteroskedastisitas.

Uji autokolerasi dalam penelitian ini bertujuan untuk menguji apakah dalam model regresi linier ada korelasi antara kesalahan penganggu pada periode $t$ dengan kesalahan pengganggu pada periode $t-1$. Model regresi yang baik adalah regresi yang bebas dari autokorelasi karena model tersebut diprediksi tidak memberikan hasil yang menyimpang.

Tabel 5. Hasil Uji Autokorelasi

\begin{tabular}{llllllrr}
\hline Model & $\mathrm{R}$ & $\begin{array}{l}\mathrm{R} \\
\text { Square }\end{array}$ & $\begin{array}{l}\text { Adjusted } \\
\text { Square }\end{array}$ & $\mathrm{R}$ & $\begin{array}{l}\text { Std. Error } \\
\text { Estimate }\end{array}$ & of the & $\begin{array}{l}\text { Durbin- } \\
\text { Watson }\end{array}$ \\
\hline 1 & 0,507 & 0,257 & 0,236 & & 0,1251208 & & 2,140 \\
\hline
\end{tabular}

Sumber: Data Penelitian, 2019 
Berdasarkan hasil uji autokorelasi pada Tabel 5. menunjukkan bahwa nilai Durbin Watson (DW test) sebesar 2,140 dengan jumlah variabel independen sebanyak $3(k=3)$, maka nilai $d_{L}=1,633$ dan $d_{U}=1,745$, sehingga $4-d_{L}=2,367$ dan $4-\mathrm{d}_{\mathrm{U}}=2,255$, maka dapat dirumuskan kriteria $\mathrm{d}_{\mathrm{U}}<\mathrm{DW}<4-\mathrm{d}_{\mathrm{U}}$ yaitu $1,745<2,140<2,255$. Hal ini menunjukkan data yang digunakan dalam penelitian ini berada pada daerah tidak terdapat autokorelasi, maka model regresi tidak mengandung gejala autokorelasi.

Analisis regresi linier berganda dapat menunjukkan arah hubungan antar variabel apakah memilki hubungan yang positif atau negatif yang digunakan untuk memecahkan masalah pada rumusan masalah yang telah dibuat yaitu menguji pengaruh diantara dua variabel atau lebih. Pada penelitian ini analisis regresi begada bertujuan untuk menguji pengaruh profitabilitas, leverage dan ukuran perusahaan pada tax avoidance di perusahaan property da real estate yang terdaftar di Bursa Efek Indonesia tahun 2014-2018. Hasil dari analisis regresi linier berganda dapat dilihat pada Tabel 6 .

Tabel 6. Hasil Analisis Regresi Linier Berganda

\begin{tabular}{lllllll}
\hline \multirow{2}{*}{ Model } & & \multicolumn{2}{l}{$\begin{array}{l}\text { Unstandardizied } \\
\text { Coefficients }\end{array}$} & \multicolumn{2}{l}{$\begin{array}{l}\text { Standardized } \\
\text { Coefficients }\end{array}$} & \\
\cline { 3 - 5 } & & $\mathrm{B}$ & Std. Error & Beta & $\mathrm{t}$ & Sig \\
\hline 1 & (Constant) & $-0,632$ & 0,249 & & $-2,533$ & 0,013 \\
& Profitabilit & & & & & \\
& as & $-0,571$ & 0,219 & $-0,227$ & $-2,601$ & 0,011 \\
& Leverage & 0,094 & 0,032 & 0,249 & 2,923 & 0,004 \\
& Ukuran P & 0,058 & 0,019 & 0,272 & 3,106 & 0,002 \\
\hline
\end{tabular}

Sumber: Data Penelitian, 2019

Berdasarkan hasil analisis regresi pada Tabel 6. maka persamaan regresi yang digunakan dalam penelitian ini dapat ditulis sebagai brikut.

$$
\mathrm{Y}=-0,632-0,571+0,094+0,058+\varepsilon
$$

Nilai konstanta (a) -0,632 menunjukkan bahwa apabila nilai variabel independen yaitu Profitabilitas, Leverage dan Ukuran Perusahaan sama dengan nol, maka besarnya tingkat penghindaran pajak adalah sebesar $-0,632$. Nilai koefisien $\beta_{1}=-0,571$ menunjukkan bahwa jika nilai profitabilitas bertambah 1 persen, maka akan terjadi peningkatan tindakan penghindaran pajak yang dilakukan perusahaan sebesar 0,571 dengan asumsi variabel lainnya konstan. Nilai koefisien $\beta_{2}=0,094$ menunjukkan bahwa jika nilai Leverage bertambah 1 persen, maka akan terjadi penurunan tindakan penghindaran pajak yang dilakukan perusahaan sebesar 0,094 dengan asumsi variabel lainnya konstan. Nilai koefisien $\beta_{3}=0,058$ menunjukkan bahwa jika nilai Ukuran Perusahaan bertambah 1 persen, maka akan terjadi penurunan tindakan penghindaran pajak yang dilakukan perusahaan sebesar 0,058 dengan asumsi variabel lainnya konstan. Nilai koefisien determinasi memiliki rentang nilai nol sampai satu $\left(0<R^{2}<1\right)$. Nilai $R^{2}$ mendekati satu berarti variabel-variabel independen memberikan hampir semua informasi yang dibutuhkan untuk memprediksi variabel dependen (Ghozali, 2016: 95). Hasil koefesien determinasi dapat dilihat pada Tabel 7. 
Tabel 7. Hasil Koefisien Determinasi

\begin{tabular}{lllll}
\hline Model & $\mathrm{R}$ & R Square & Adjusted R Square & Std. Errorof the Estimate \\
\hline 1 & 0,507 a & 0,257 & 0,236 & 0,1251208 \\
\hline \multicolumn{2}{l}{ Sumber: Data Penelitian, 2019} & &
\end{tabular}

Berdasarkan Tabel 7. dapat dilihat bahwa nilai Adjusted $R$ Square pada model sebesar 0,236. Nilai koefisien determinasi dapat dirumuskan sebagai berikut $0<0,236<1$. Nilai Adjusted $R$ Square pada model artinya variabel Tax avoidance dapat dijelaskan oleh variabel Profitabilitas, Leverage dan Ukuran Perusahaan sebesar 23,6 persen, sedangkan sisanya 77,4 persen dijelaskan oleh variabel lain diluar model regresi. Standar Error of the Estimate (SEE) sebesar 0,125 , yang artinya semakin kecil nilai SEE akan membuat model regresi semakin tepat dalam memprediksi variabel independen.

Uji kelayakan model regresi digunakan untuk menguji kelayakan atau validitas dari suatu model regresi. Uji F bertujuan untuk mengetahui apakah semua variabel independen dalam model regresi mempunyai pengaruh secara simultan terhadap variabel dependen. Pengujian ini dilakukan dengan menggunakan tingkat signifikansi $a=0,05$. Kriteria pengujian dengan tingkat signifikansi 0,05 yaitu bila nilai signifikansi $\mathrm{F} \leq 0,05$ maka Ho ditolak yang artiya terdapat pengaruh yang signifikan antara semua variabel independen pada variabel dependen, sedangkan bila nilai signifikansi F >0,05 maka Ho diterima yang artiya semua variabel independen tidak berpengaruh pada variabel dependen. Hasil uji kelayakan model (uji F) dapat dilihat pada Tabel 8.

Tabel 8. Hasil Uji Kelayakan Model

\begin{tabular}{lllllll}
\hline Model & & Sum of Square & Df & Mean Square & F & Sig \\
\hline 1 & Regression & 0,574 & 3 & 0,191 & 12,230 & $0,000^{a}$ \\
& Residual & 1,659 & 106 & 0,016 & & \\
& Total & 2,234 & 109 & & & \\
\hline
\end{tabular}

Sumber: Data Penelitian, 2019

Berdasarkan hasil uji kelayakan model pada Tabel 8. dapat diketahui bahwa hasil perhitungan $\mathrm{F}$ menunjukkan angka sebesar 12,230 dengan tingkat signifikansi 0,000 lebih kecil dari a = 0,05 sehingga dapat disimpulkan bahwa model ini layak digunakan dalam penelitian. Sesuai dengan kriteria pengujian dengan tingkat signifikansi 0,05 yaitu F $\leq 0,05$ maka Ho ditolak, artinya terdapat pengaruh yang signifikan antara semua variabel independen terhada $p$ variabel dependen.

Uji hipotesis dalam penelitian ini dilakukan untuk mengetahui pengar uh suatu variabel bebas yaitu profitabilitas $\left(X_{1}\right)$, leverage $\left(X_{2}\right)$ dan ukuran perusahaan $\left(X_{3}\right)$ secara individual menerangkan variasi variabelterikat yaitu tax avoidance yang diproksikan dengan CETR (Y). Uji t dilakukan dengan tujuan apakah dalam model regresi variabel bebas secara parsial berpengaruh signifikan pada variabel terikat, dengan asumsi nilai signifikan uji $\mathrm{t} a=0,05$ dengan kriteria pertama, jika nilai signifikansi > 0, 05 maka koefisien regresi tidak signifikan. Hal ini berarti secara parsial variabel independen tersebut mempunyai pengaruh yang signifikan terhadap variabel dependen. Hasil uji statistik $t$ dapat dilihat pada Tabel 9. 
Tabel 9. Hasil Uji Statistikt

\begin{tabular}{lllll}
\hline Variabel & Koefisien Regresi & $\mathrm{t}_{\text {hitung }}$ & Sig. & Hasil Hipotesis \\
\hline Profitabilitas $\left(\mathrm{X}_{1}\right)$ & $-0,571$ & $-2,601$ & 0,011 & $\mathrm{H}_{1}$ diterima \\
Leverage $\left(\mathrm{X}_{2}\right)$ & 0,094 & 2,923 & 0,004 & $\mathrm{H}_{2}$ ditolak \\
Ukuran Perusahaan $\left(\mathrm{X}_{3}\right)$ & 0,058 & 3,106 & 0,002 & $\mathrm{H}_{3}$ ditolak \\
\hline
\end{tabular}

Sumber: Data Penelitian, 2019

Berdasarkan hasil uji statistik $t$ pada Tabel 9. diketahui bahwa profitabilitas yang pengukurannya diproksikan dengan ROA menunjukkan nilai $t_{\text {hitung }}=-2,601$ dengan tingkat signifikansi 0,011. Nilai signifikansi lebih kecil d ari $a=0,05$ atau nilai $0,011<0,05$ dengan arah koefisien regresi bernilai negatif sebesar -0,571. Berdasarkan hal tersebut, menunjukkan bahwa variabel profitabilitas berpengaruh negatif dan signifikan pada CETR sebagai proksi tax avoidance. Semakin kecil nilai CETR maka semakin besar tindakan tax avoidance dan sebaliknya. Hasil pengujian ini menunjukkan bahwa profitabilitas berpengaruh positif pada tax avoidance, sehingga hipotesis pertama diterima.

Leverage yang pengukurannya diproksikan dengan DER menunjukkan nilai $t_{\text {hitung }}=2,923$ dengan tingkat signifikansi 0,004. Nilai signifikansi lebih kecil dari $\alpha=0,05$ atau nilai $0,004<0,05$ dengan arah koefisien regresi bernilai positif sebesar 0,094. Berdasarkan hal tersebut, menunjukkan bahwa variabel leverage berpengaruh positif dan signifikan pada CETR sebagai proksi tax avoidance. Semakin besar nilai CETR maka semakin kecil tindakan tax avoidance dan sebaliknya. Hasl pengujian ini menunjukkan bahwa leverage berpengaruh negatif pada tax avoidance, sehingga hipotesis kedua ditolak.

Ukuran perusahaan yang pengukurannya diproksikan dengan Log total aset menunjukkan nilai $t_{\text {hitung }}=3,106$ dengan tingkat signifikansi 0,002 . Nilai signifikansi lebih kecil dari $\alpha=0,05$ atau nilai $0,002<0,05$ dengan arah koefisein regresi bernilai positif yaitu 0,058. Berdasarkan hal tersebut, menunjukkan bahwa variabel ukuran perusahaan berpengaruh positif dan signifikan pada CETR sebagai proksi tax avoidance. Semakin besar nilai CETR maka semakin kecil tindakan tax avoidance dan sebaliknya. Hasl pengujian ini menunjukkan bahwa ukuran perusahaan berpengaruh negatif pada tax avoidance, sehingga hipotesis ketiga ditolak.

\section{SIMPULAN}

Hasil dari penelitian ini yaitu perusahaan dengan tingkat profitabilitas Profitabilitas berpengaruh positif pada tax avoidance, yang diproksikan dengan rasio Return on assets. Semakin tinggi nilai $\mathrm{ROA}$, maka semakin tinggi juga profit yang diperoleh perusahaan. Profit perusahaan yang tinggi menggambarkan bahwa adanya kinerja keuangan yang bagus didalam suatu perusahaan dalam menghasilkan laba yang tinggi dari pengelolaan aktivanya. Semakin tinggi profitabilitas maka nilai CETR semakin rendah. Artinya semakin tinggi profitabilitas perusahaan maka tax avoidance perusahaan meningkat.

Leverage berpengaruh negatif pada tax avoidance, yang diproksikan dengan rasio Debt to Equity Ratio. Semakin tinggi tingkat hutang suatu perusahaan, maka tidak akan mempengaruhi adanya praktik tax avoidance. Hal tersebut terjadi dikarenakan semakin tinggi tingkat hutang suatu perusahaan maka pihak manajemen akan lebih konservatif dalam melakukan pelaporan 
keuangan atau operasional perusahaan. Leverage pada penelitian ini menunjukkan bahwa berpengaruh negatif pada tax avoidance.

Ukuran perusahaan berpengaruh negatif pada tax avoidance, yang diproksikan dengan log total aset. Perusahaan yang besar akan berusaha membayar pajak sesuai dengan jumlah yang diharuskan dalam peraturan perpajakan, karena semakin besar perusahaan maka semakin besar pengaw asan yang diberikan kepada perusahaan oleh pemerintah yang mengakibatkan perusahaan tersebut mengurangi tindakan tax avoidance. Selain itu semakin besar ukuran perusahaan maka perusahaan dapat menggunakan fasilitas perpajakan berupa insentif pajak.

\section{REFERENSI}

Arianandini, P. W., \& Ramantha, I. W. (2018). Pengaruh Profitabilitas, Leverage, dan Kepemilikan Institusional Pada Tax Avoidance. E-Jurnal Akuntansi, 22, 2088. https://doi.org/10.24843/eja.2018.v22.i03.p17

Amstrong, C., et al. (2015). Corporate Governance, Incentive, and Tax avoidance. Jurnal of Accounting and Economics, Volume 60.

Ayuningtyas, N. P. W., \& Sujana, I. K. (2018). Pengaruh Proporsi Komisaris Independen, Leverage, Sales Growth, Dan Profitabilitas Pada Tax Avoidance Ni. E-Jurnal Akuntansi Universitas Udayana, 25, 1884-1912.

Darmawan, I Gede Hendy., Sukartha, I M. (2014). Pengaruh Penerapan Corporate Governance, Leverage, Return On Assets , Dan Ukuran Perusahaan Pada Penghindaran Pajak, E-Jurnal Akuntansi Universitas Udayana, 143-161.

Dewinta, I. A. R., \& Setiawan, P. E. (2016). Pengaruh Ukuran Perusahaan, Umur Perusahaan, Profitabilitas, Leverage, Dan Pertumbuhan Penjualan Terhadap Tax Avoidance. E-Jurnal Akuntansi Universitas Udayana, 14(3), 1584-1613.

Dharma, I Made Surya, Ardiana, P. A. (2016). Pengaruh Leverage, Intensitas Aset Tetap, Ukuran Perusahaan, Dan Koneksi Politik Terhadap Tax Avoidance. EJurnal Akuntansi Universitas Udayana, 15, 584-613.

Diantari, Putu Rista., Ulupui, I. A. (2016). Pengaruh Komite Audit, Proporsi Komisaris Independen, Dan Proporsi Kepemilikan Institusional Terhadap Tax Avoidance. E-Jurnal Akuntansi Universitas Udayana, 16, 702-732.

Direktorat Jenderal Pajak Kementrian Keuangan. Data Mengenai Penerimaan Pajak. Retrieved from http://pajak.go.id/content/penerimaan-pajak-tahunberjalan

Direktorat, Jenderal, Pajak. Undang-Undang Republik Indonesia Nomor 28 Tahun 2007 tentang Ketentuan Umum dan Tata Cara Perpajakan.

Febriana. (2017). Febriana, Galih Rahayu. (2017). Pengaruh Profitabilitas, Leverage, Ukuran Perusahaan dan Capital Intensity Terhadap Tax Avoidance. Fakultas Ekonomi dan Bisnis Unpas Bandung. Journal of Financial Economics, 49-80.

Handayani, R. (2017). Pengaruh Return on Assets (ROA), Leverage dan Ukuran Perusahaan Terhadap Tax Avoidance Pada Perusahaan Perbankan yang Listing di BEI Periode Tahun 2012-2015. Edisi Kelima Semarang: Bandan Penerbitan Universitas Diponegoro, 10, 1-13. Retrieved from http://journal.maranatha.edu 
Kurniasih, T., \& Sari, M. M. (2013). Pengaruh Profitabilitas, Leverage, Cor porate Governance, Ukuran Perusahaan dan Kompensasi Rugi Fiskal pada Tax Avoidance. Buletin Studi Ekonomi, 18, 58-66.

Maharani, I. G. A. C., \& Suardana, K. A. (2014). Pengaruh Corporate Governance, Profitabilitas dan Krakteristik Eksekutif pada Tax Avoidance. E-Jurnal Akuntansi Universitas Udayana.

Praditasari, Komang Ayu; Setiawan, P. E. (2017). Pengaruh Good Corporate Governance, Ukuran Perusahaan, Leverage Dan Profitabilitas Pada Tax Avoidance. E-Jurnal Akuntansi Universitas Udayana, 19, 1229-1258.

Putri, V. R., \& Putra, B. I. (2017). Pengaruh, Leverage, Profitability, Ukuran Perusahaan Dan Proporsi Kepemilikan Institusional Terhadap Tax Avoidance. Jurnal Ekonomi Manajemen Sumber Daya, 19, 1-11.

Rinaldi. \& Cheisviyanny, C. (2015). Pengaruh Profitabilitas, Ukuran Perusahaan dan Kompensasi Rugi Fiskal terhadap Tax Avoidance. SNEMA Fakultas Ekonomi Universitas Negeri Padang., ISBN: 978-.

Sa'diyah, I. (2016). Pengaruh Keadilan, Sistem Perpajakan, Diskriminasi, dan Kemungkinan Terdeteksi Kecurangan Terhadap Presepsi Wajib Pajak Mengenai Perilaku Etika Penggelapan Pajak (Tax Evasion). Universitas Muhammadyah Gresik.

Saputra, Muhammad Fajri., Rifa, Dandes, Rahmawati, N. (2015). Pengaruh Corporate Governance, Profitabilitas Dan Karakter Eksekutif Terhadap Tax Avoidance. Universitas Bung Hatta, JAAI Vol 1.

Swingly, Calvin, Sukartha, I. M. (2015). Pengaruh Karakter Eksekutif, Komite Audit, Ukuran Perusahaan, Leverage Dan Sales Growth Pada Tax Avoidance. E-Jurnal Akuntansi Universitas Udayana, 1, 47-62.

Utari, N. K.Y., \& Supadmi, N. L. (2017). Pengaruh Corporate Governance, Profitabilitas dan Koneksi Politik pada Tax Avoidance. E-Jurnal Akuntansi Universitas Udayana, 18, 2202-22.

Waluyo A, Culbert GJ, Levy J, N. K. (2015). Understanding HIV-related stigma among Indonesian nurses. J Assoc Nurses AIDS Care. 26(1):69-80. Doi:10.1016/j.Jana.2014.03.001. 